\title{
Environment and Food Production in Papua New Guinea
}

\author{
R. Michael Bourke
}

\section{Introduction}

The physical environment plays a critical role in determining both where crops can be grown and how productive they are. The environment in which plants grow can be modified to some degree by people, for example, using drainage to reduce excessive soil moisture. Here the main physical environmental factors that influence crop growth in Papua New Guinea (PNG) are noted and their influence on crop distribution and productivity is reviewed. This research builds on the pioneering work of Harold Brookfield (1964) on the ecology of human settlement in New Guinea over half a century ago. The focus here is on those crops that were used in PNG before the recent adoption of numerous introduced species. Most of these new crops appeared after 1870 following sustained European contact, but sweet potato came into PNG via Southeast Asia about 300 years ago (Ballard 2005: 9; Bayliss-Smith et al. 2005: 109). Tobacco, another American plant, was present in west New Guinea about 400 years ago (Ballard 2005: 8).

I pay more attention to the impact of temperature as small differences can have a significant influence on both the distribution and productivity of crops, particularly near their environmental margins. Greater emphasis is also given to the PNG highlands than to the lowlands or the intermediate zone because the focus of this volume is on the Kuk archaeological site and the Wahgi Valley in the highlands. The environmental factors considered here, besides temperature, are soil moisture (including flooding), cloud cover, slope, day length and soil fertility.

The most important determinant of temperature differences in PNG is altitude. There are a number of other factors that have a minor influence on temperature, including distance from the equator, seasonal rainfall distribution, total land mass and aspect. But it is altitude that is the dominant factor, with temperatures declining in a linear manner with increasing altitude. With increasing altitude, the crop base becomes smaller, so that, at the upper limit for agriculture in PNG, people are dependent on a limited number of species, most of which are recent introductions. ${ }^{1}$

\footnotetext{
1 The upper limit of village agriculture now occurs at about $2700 \mathrm{~m}$ in the PNG highlands, as this is the upper limit for sweet potato production. In a limited number of locations, food gardens are made as high as $2850 \mathrm{~m}$, while some foods are collected from wild plants as high as $3300 \mathrm{~m}$, for example, wild karuka nut pandanus (Pandanus brosimos).
} 
Available soil moisture for plants is determined by rainfall, slope, soil texture, soil depth, runoff, evaporation and drainage. Inundation or flooding is an extreme soil moisture condition that has a marked impact on both crop distribution and productivity. Deficiency of soil moisture can be corrected through irrigation (which is uncommon in contemporary PNG) and its excess through mounding or drainage, which are techniques widely used, particularly for growing sweet potato in the highlands (see Chapter 5).

Cloud cover is determined by both total annual rainfall and terrain. Excessive cloud cover limits crop productivity. Day length does not have a huge bearing on crop distribution or productivity in PNG, as most of the country lies within 12 degrees of the equator. Its main impact is to determine the flowering patterns of certain species, particularly fruit and nut crops. Soil fertility has a major influence on the productivity of plants. It is determined by the inherent fertility of the land, slope, fallow period, cropping period and human efforts to enhance it.

\section{The food crop base before 1870}

Our attention now turns to the crop base for subsistence food crop production before the introduction of sweet potato about 300 years ago and of numerous other food plants from the Americas, Europe and Africa, as well as elsewhere in the Asia Pacific region, after about 1870. The food crops can be grouped as staples (providing most of the food energy), vegetables, fruits and nuts. Between 1979 and 1984, I recorded the altitudinal range of 230 crop species in PNG (Bourke 2010). Some of these data, presented in Tables $4.1-4.4,{ }^{2}$ are utilised in the section on the influence of temperature on crop distribution and production. Data on the altitudinal range of three staple food crops (taro, banana and yam) are also used to draw conclusions as to whether these crops could grow in the Kuk area at different periods in the past.

The most important of the staple foods in PNG before the introduction of sweet potato and other crops from the Americas were Colocasia taro, banana, yam (Dioscorea esculenta and D. alata) and sago. Breadfruit was an important seasonal food in some locations. On the island of New Guinea, breadfruit seeds were roasted and consumed. On smaller islands, including those in the Bismarck Archipelago and Solomon Islands chain, and at a limited number of locations in New Guinea, breadfruit flesh was also eaten.

Sugarcane was a useful but minor source of food energy in many locations. Other minor species included swamp taro, used particularly on atolls and some of the larger islands, giant taro (Alocasia), Amorphophallus taro, three other species of yam (D. bulbifera, D. nummularia and D. pentaphylla) and pueraria, a minor and now unimportant tuber crop. Swamp taro, giant taro, Amorphophallus taro, sago and breadfruit do not grow in the highlands (Table 4.1). Of the species mentioned here, only sugarcane grows at more than $2400 \mathrm{~m}$. Before the adoption of sweet potato about 300 years ago, the most likely staple food in the highlands over an altitudinal range of 1200 to $2200 \mathrm{~m}$ was taro, supplemented by banana and D. alata yam, (but see Chapter 14 , where a case for the replacement of taro by yam and banana is argued for the period before the arrival of the sweet potato).

2 Some common names from PNG are used in the text. See the tables for botanical names. 
Table 4.1 Altitudinal range of pre-1870 starchy food species in PNG.

\begin{tabular}{|c|c|c|c|c|c|}
\hline \multirow[t]{2}{*}{ Scientific name } & \multirow[t]{2}{*}{ Common name } & \multirow{2}{*}{$\begin{array}{l}\text { Mean usual } \\
\text { altitudinal } \\
\text { range (m) }\end{array}$} & \multirow{2}{*}{$\begin{array}{l}\text { Extreme } \\
\text { altitudinal } \\
\text { range (m) }\end{array}$} & \multicolumn{2}{|c|}{$\begin{array}{c}\text { Number of observations/ } \\
\text { standard deviation }\end{array}$} \\
\hline & & & & Usual min. & Usual max. \\
\hline Alocasia macrorrhizos ${ }^{1}$ & Giant taro & $0-?$ & $0-?$ & - & - \\
\hline Amorphophallus paeoniifolius & Amorphophallus taro & $0-700$ & $0-1230$ & - & $4 / 50$ \\
\hline Artocarpus altilis & Breadfruit & $0-1250$ & $0-1450$ & - & $23 / 130$ \\
\hline Colocasia esculenta ${ }^{2}$ & Таго & $0-2400$ & $0-2760$ & - & $17 / 150$ \\
\hline Cyrtosperma chamissonis & Swamp taro & $0-50 ?$ & $0-?$ & - & \\
\hline Dioscorea alata & Greater yam & $0-1900$ & $0-2100$ & - & $15 / 80$ \\
\hline Dioscorea bulbifera & Potato yam & $0-1900$ & $0-2110$ & - & $12 / 110$ \\
\hline Dioscorea esculenta ${ }^{3}$ & Lesser yam & $0-1550$ & $0-1670$ & - & $4 / 120$ \\
\hline Dioscorea nummularia & Nummularia yam & $0-1900$ & $0-2050$ & - & $7 / 90$ \\
\hline Dioscorea pentaphylla & Five leaflet yam & $0-1500$ & $0-1620$ & - & $3 / 40$ \\
\hline Ipomoea batatas & Sweet potato & $0-2700$ & $0-2850$ & - & $10 / 150$ \\
\hline Metroxylon sagu & Sago & $0-1150$ & $0-1250$ & - & $10 / 60$ \\
\hline Musa cvs & Fe'i banana & $0-1750$ & $0-2060$ & - & $8 / 160$ \\
\hline Musa cvs & Diploid banana & $0-1800$ & $0-2030$ & - & $19 / 70$ \\
\hline Musa cvs & Triploid banana & $0-2150$ & $0-2580$ & - & $30 / 130$ \\
\hline Pueraria lobata & Pueraria & $0-2300$ & $0-2740$ & - & $5 / 180$ \\
\hline Saccharum officinarum & Sugarcane & $0-2600$ & $0-2760$ & - & $8 / 160$ \\
\hline
\end{tabular}

Source: Bourke (2010), reproduced with permission.

Notes:

1 Self-sown Alocasia sp. taro grows as high as $2640 \mathrm{~m}$, but Alocasia macrorrhizos is planted as a food crop only at low altitudes.

2 The figures for colocasia taro are for single plants, but plots of taro are not planted as high as individual plants. The highest observed plot of taro plants was at $2370 \mathrm{~m}$ (Sau Valley, Enga) and the mean of six observations was $2250 \pm 100 \mathrm{~m}$.

${ }^{3}$ Dioscorea esculenta yam is not common above $900 \mathrm{~m}$.

${ }^{4}$ Sweet potato was introduced into PNG about 300 years ago (see Chapter 16). The usual upper limit of sweet potato $(2700 \mathrm{~m})$ is derived from the 10 highest observations.

A very large number of leafy green and other vegetables was consumed, including aibika, Amaranthus tricolor, cucumber, fern fronds, Ficus copiosa leaves and fruit, ginger, hyacinth beans, Rorippa schlechteri leaves, taro leaves, tulip, oenanthe, winged bean tubers and beans, rungia, lowland pitpit and highland pitpit. Many other species are now used as minor vegetables and some are likely to have been more important in the past. The number of species that could be grown above an altitude of $2200 \mathrm{~m}$ was limited, with Rorippa schlechteri, oenanthe, rungia and highland pitpit the most important of the pre-contact species now grown above $2200 \mathrm{~m}$ altitude (Table 4.2).

Some of the pre-1870 fruit species had a limited spatial distribution, for example bukabuk (Burckella obovata), which was eaten on the islands of Milne Bay, on New Ireland and the Gazelle Peninsula of New Britain, but had minor importance elsewhere. Dracontomelon dao was a significant fruit near Madang, as was Pouteria maclayana, but both were unimportant or absent elsewhere in the lowlands. Similarly Parartocarpus venenosa was mainly consumed on $\mathrm{New}$ Britain, although it was known and eaten in some other lowland locations. The most widely consumed fruits were traditional mango, marita pandanus, ton, golden apple and Malay apple. Marita pandanus was grown very widely on the island of New Guinea up to the lower highland valleys at an altitude of $1700 \mathrm{~m}$, and it was the only significant fruit species in the highlands (Table 4.3). It was (and is) used to make a sauce rich in oil and Vitamin A to flavour bland root crops and banana. 
Table 4.2 Altitudinal range of some pre-1870 vegetable species in PNG.

\begin{tabular}{|c|c|c|c|c|c|}
\hline \multirow[t]{2}{*}{ Scientific name } & \multirow[t]{2}{*}{ Common name } & \multirow{2}{*}{$\begin{array}{l}\text { Mean usual } \\
\text { altitudinal } \\
\text { range (m) }\end{array}$} & \multirow{2}{*}{$\begin{array}{l}\text { Extreme } \\
\text { altitudinal } \\
\text { range }(m)\end{array}$} & \multicolumn{2}{|c|}{$\begin{array}{l}\text { Number of observations/ } \\
\text { standard deviation }\end{array}$} \\
\hline & & & & Usual min. & Usual max. \\
\hline Abelmoschus manihot & Aibika & 0-1900 & $0-2110$ & - & $20 / 110$ \\
\hline Amaranthus tricolor & Amaranth & $0-1950$ & $0-2050$ & - & $11 / 50$ \\
\hline Caryota rumphiana & Fishtail palm & $0-1250$ & $0-1600$ & - & $10 / 70$ \\
\hline Commelina diffusa & Wandering Jew & $0-?$ & $0-2390$ & - & - \\
\hline Cucumis sativus & Cucumber & 0-1950 & $0-2210$ & - & $19 / 80$ \\
\hline Cyanotis moluccana & - & 0-? & $0-2410$ & - & - \\
\hline Cymbopogon citratus & Lemon grass & $0-?$ & $0-2140$ & - & - \\
\hline Desmodium repandum & - & $?-2250$ & $1100-2350$ & - & $6 / 80$ \\
\hline Dicliptera рарuапа & - & $1000-2000$ & $720-2660$ & $6 / 220$ & $5 / 170$ \\
\hline Erythrina variegata & Indian coral tree & 0-1550 & $0-2210$ & - & $9 / 170$ \\
\hline Ficus copiosa & Kumu musong & $0-2200$ & $0-2450$ & - & $6 / 140$ \\
\hline Ficus dammaropsis & Highland kapiak & $800-2750$ & $0-2820$ & $5 / 300$ & $3 / 60$ \\
\hline Ficus pungens & - & 0-1850 & $0-1900$ & - & $5 / 60$ \\
\hline Ficus wassa & - & $0-?$ & $0-2520$ & - & - \\
\hline Gnetum gnemon² & Tulip & $0-1100$ & $0-1330$ & - & $10 / 150$ \\
\hline Graptophyllum pictum & - & $0-?$ & $0-1730$ & - & - \\
\hline Lablab purpureus & Hyacinth bean & $0-2000$ & $0-2430$ & - & $15 / 170$ \\
\hline Lagenaria siceraria & Bottle gourd & $0-?$ & $0-2670$ & - & - \\
\hline Oenanthe javanica & Oenanthe & $1050-2700$ & $0-3400$ & $9 / 220$ & $3 / 40$ \\
\hline Pipturus argenteus & - & 0-1800 & $0-1950$ & - & $5 / 90$ \\
\hline Polyscias sp. & Valangur & $0-1200$ & $0-1230$ & - & $4 / 30$ \\
\hline Psophocarpus tetragonolobus ${ }^{4}$ & Winged bean & $0-1900$ & $0-2070$ & - & $28 / 90$ \\
\hline Ricinus communis & Castor & $0-2350$ & $0-2760$ & - & $5 / 100$ \\
\hline Rorippa schlechterז & - & $750-2700$ & $180-2850$ & $4 / 120$ & $4 / 120$ \\
\hline Rungia klossif & Rungia & $950-2700$ & $0-2760$ & $10 / 170$ & $4 / 40$ \\
\hline Saccharum edule & Lowland pitpit & $0-1800$ & $0-2270$ & - & $23 / 160$ \\
\hline Setaria palmifolia ${ }^{7}$ & Highland pitpit & $0-2700$ & $0-2760$ & - & $4 / 40$ \\
\hline Solanum americanum & Nightshade & $0-2550$ & $0-2800$ & - & $6 / 190$ \\
\hline Trichosanthes pulleana & - & $0-2000$ & $0-2200$ & - & $3 / 80$ \\
\hline Zingiber officinale & Ginger & 0-1950 & $0-2200$ & - & $15 / 80$ \\
\hline
\end{tabular}

Source: Bourke (2010), reproduced with permission.

Notes:

1 Dicliptera papuana is given as Hemigraphis sp. by some authors.

2 Gnetum gnemon produces both edible nuts and leaves over these altitudinal ranges.

${ }^{3}$ Oenanthe is planted in food gardens up to the altitudinal limit of gardening (about $2700 \mathrm{~m}$ ) in Enga and Simbu. Self-sown plants occur as high as $3000 \mathrm{~m}$ in Enga and $3400 \mathrm{~m}$ in Simbu. The mean usual lower limit of $1050 \mathrm{~m}$ is for locations where oenanthe was traditionally grown. It is now commonly planted in coastal locations by highland migrants.

${ }^{4}$ The usual range for all plantings of winged bean is from sea level to $1900 \mathrm{~m}$. This species is planted mainly for tuber production over the range of 1200-1900 m.

${ }^{5}$ Rorippa schlechteri is sometimes identified as Nasturtium sp.

${ }^{6}$ Rungia is planted up to about $2700 \mathrm{~m}$, for example on the Sirunki Plateau and in the Kaugel, Wage and Chimbu Valleys. It is not common above about $2300 \mathrm{~m}$.

${ }^{7}$ While Setaria palmifolia is grown between sea level and $2700 \mathrm{~m}$, it is more commonly planted above about $500 \mathrm{~m}$. 
Table 4.3 Altitudinal range of some pre-1870 fruit species in PNG.

\begin{tabular}{|c|c|c|c|c|c|}
\hline \multirow[t]{2}{*}{ Scientific name } & \multirow[t]{2}{*}{ Common name } & \multirow{2}{*}{$\begin{array}{l}\text { Mean usual } \\
\text { altitudinal } \\
\text { range }(m)\end{array}$} & \multirow{2}{*}{$\begin{array}{l}\text { Extreme } \\
\text { altitudinal } \\
\text { range (m) }\end{array}$} & \multicolumn{2}{|c|}{$\begin{array}{l}\text { Number of observations/ } \\
\text { standard deviation }\end{array}$} \\
\hline & & & & Usual min. & Usual max. \\
\hline Burckella obovata & Bukabuk & $0-?$ & $0-390$ & - & - \\
\hline Mangifera minor & Traditional mango & $0-1750$ & $0-1900$ & - & $6 / 100$ \\
\hline Pandanus conoideus ${ }^{1}$ & Marita & $0-1700$ & $0-1980$ & - & $37 / 90$ \\
\hline Parartocarpus venenosa² & - & $0-?$ & $0-?$ & - & - \\
\hline Pometia pinnata ${ }^{3}$ & Ton & $0-800$ & $0-1120$ & - & $7 / 160$ \\
\hline Rubus moluccanus & Red raspberry & $0-2150$ & $0-2250$ & - & $3 / 120$ \\
\hline Rubus rosifolius & Red raspberry & $950-2800$ & $700-2900$ & $8 / 180$ & $5 / 60$ \\
\hline Spondias cytherea & Golden apple & $0-950$ & $0-1070$ & - & $4 / 110$ \\
\hline Syzygium malaccense & Malay apple & $0-850$ & $0-1580$ & - & $5 / 80$ \\
\hline
\end{tabular}

Source: Bourke (2010), reproduced with permission.

Notes:

${ }^{1}$ Marita pandanus is not usually planted near the ocean, but it is grown in inland areas at altitudes below $100 \mathrm{~m}$, for example near Kiunga, Popondetta and Aitape and in the Gogol Valley. It is more commonly planted above about $500 \mathrm{~m}$.

${ }^{2}$ The upper altitudinal limit for Parartocarpus venenosa is not known, but it is a lowland species.

3 Pometia pinnata bears edible fruit up to a mean upper limit of $800 \mathrm{~m}$, but the tree grows at higher altitudes. It has been recorded at about $1700 \mathrm{~m}$ in the Nipa area of the Southern Highlands Province.

Table 4.4 Altitudinal range of some pre-1870 edible nut species in PNG.

\begin{tabular}{|c|c|c|c|c|c|}
\hline \multirow[t]{2}{*}{ Scientific name } & \multirow[t]{2}{*}{ Common name } & \multirow{2}{*}{$\begin{array}{l}\text { Mean usual } \\
\text { altitudinal } \\
\text { range }(m)\end{array}$} & \multirow{2}{*}{$\begin{array}{l}\text { Extreme } \\
\text { altitudinal } \\
\text { range }(\mathrm{m})\end{array}$} & \multicolumn{2}{|c|}{$\begin{array}{l}\text { Number of observations/ } \\
\text { standard deviation }\end{array}$} \\
\hline & & & & Usual min. & Usual max. \\
\hline Aleurites moluccana & Candle nut & $0-1800$ & $0-2160$ & - & $9 / 140$ \\
\hline Artocarpus altilis & Breadfruit & $0-1250$ & $0-1450$ & - & $23 / 130$ \\
\hline Barringtonia procera & Pao & $0-500$ & $0-620$ & - & $4 / 90$ \\
\hline Canarium indicum & Galip & $0-700$ & $0-930$ & - & $5 / 160$ \\
\hline Castanopsis acuminatissima' & Castanopsis & $700-2350$ & $570-2440$ & $6 / 80$ & $8 / 110$ \\
\hline Cocos nucifera² & Coconut & 0-950 & $0-1310$ & - & $20 / 190$ \\
\hline Finschia chloroxantha & Finschia & $0-1850$ & $0-2000$ & - & $4 / 110$ \\
\hline Inocarpus fagifer & Polynesian chestnut & $0-400$ & $0-870$ & - & $4 / 90$ \\
\hline Pandanus antaresensis & Wild karuka & $1000-2350$ & $850-2460$ & $4 / 110$ & $9 / 90$ \\
\hline Pandanus brosimos & Wild karuka & $2400-3100$ & $1800-3300$ & $20 / 150$ & $6 / 60$ \\
\hline Pandanus julianettii & Karuka & $1800-2600$ & $1450-2800$ & $50 / 110$ & $18 / 100$ \\
\hline Pangium edule & Sis & $0-1050$ & $0-1380$ & - & $11 / 120$ \\
\hline Terminalia catappa & Sea almond (talis) & $0-300$ & $0-460$ & - & $4 / 100$ \\
\hline Terminalia impediens & Okari & $0-1000$ & $0-1100$ & - & $3 / 110$ \\
\hline Terminalia kaernbachii & Okari & $0-1100$ & $0-1260$ & & $11 / 90$ \\
\hline
\end{tabular}

Source: Bourke (2010), reproduced with permission.

Notes:

${ }^{1}$ Self-sown Castanopsis is more common above about $1100 \mathrm{~m}$, although the usual mean lower limit is $700 \mathrm{~m}$.

${ }^{2}$ In the period 1980-82, coconut palms grew as high as $1760 \mathrm{~m}$, but the highest altitude that they bore nuts was at Yonki, Eastern Highlands Province (EHP) (1310 m), and the Baiyer Valley, Western Highlands Province (WHP) (1220 m). By 1999, palms were bearing as high as $1370 \mathrm{~m}$ (Benabena, EHP), $1420 \mathrm{~m}$ (Korofeigu, EHP) and $1450 \mathrm{~m}$ (Wahgi Valley, WHP). By mid-2009, they were bearing as high as $1560 \mathrm{~m}$ (near Goroka, EHP). This trend is attributed to increasing temperatures associated with climate change. The information is taken from the author's field notebooks. 
The most important nut-bearing plants were coconut, breadfruit, various pandanus and okari. Coconut was presumably an important source of food energy in coastal locations, given that it was (and continues to be) widely used for cooking there. Most of the other nut-bearing species did not produce above an altitude of about $1200 \mathrm{~m}$. An important exception is the nutbearing pandanus. Planted karuka nut (Pandanus julianettii) was an important food crop over an altitudinal range of 1800-2600 $\mathrm{m}$ and its relative, wild karuka (P. brosimos), over a higher range of 2400-3100 m (Table 4.4). Minor nut-bearing species in the highlands were castanopsis, sometimes consumed in the western and southern parts of the highlands, candle nut (Aleurites moluccana) and Finschia chloroxantha.

A number of important staple foods are now believed to be indigenous to and domesticated in the New Guinea region: Colocasia taro, banana, breadfruit, sago, sugarcane and two of the yam species, Dioscorea alata and D. bulbifera (Yen 1991a; Lebot 1999; Denham, Haberle and Lentfer 2004; see Chapter 3). Vegetables, fruits and nuts that were domesticated in the New Guinea area include oenanthe, rungia, lowland pitpit, highland pitpit, Rorippa schlechteri, marita pandanus, bukabuk, ton, okari nut and wild and planted karuka pandanus.

Some of the species that have been recorded since European contact as minor foods may have been much more important foods in the past. There are many examples of recently introduced species displacing or supplementing established ones since the 1870s (or some 200 years earlier in the case of sweet potato). ${ }^{3}$ Newly adopted species, besides sweet potato, include cassava, Xanthosoma taro, maize, tobacco, peanuts, round cabbage, Chinese cabbage, Amaranthus cruentus and many fruits, such as mango, pineapple, pawpaw and mandarin. This suggests that people will readily adopt introduced foods that they consider to be superior, but do not completely discard the older species.

Sometimes there are indications that a species may have been adopted more recently than other species. For example, Dioscorea esculenta may have made a late appearance in the region and thus been used there for a shorter period than the other yam species. The evidence suggests that this occurred after the appearance of the archaeological Lapita culture in the Bismarck Archipelago some 3300 years ago. ${ }^{4}$ The species is agronomically superior to other yam species in PNG, including $D$. alata, with fewer disease problems, a higher tuber yield per plant and tubers that are more easily prepared for cooking than those of most varieties of other species. It is also the most widely grown yam species in the PNG lowlands up to about $900 \mathrm{~m}$ altitude. ${ }^{5}$ Despite this, it is less important for ritual purposes than the other yam species, particularly D. alata, suggesting that it has been adopted because of its ability to provide food energy, while the other species have been retained for other values and purposes.

\footnotetext{
3 See Bourke (2009) for a list of 180 food crops and stimulants in four groups according to the length of time that the crops have been in PNG.

4 This is because linguists cannot reconstruct a word for the species in Proto Oceanic (Ross 2008: 258, 263), the language of the Austronesian-speaking migrants who are thought to be associated with the beginning of the Lapita culture at this time (Spriggs 2010: 129; on the dating see Summerhayes 2010: 13-24). For another opinion on the history of D. esculenta in New Guinea see Chapter 10, footnote 1 .

5 Dioscorea esculenta accounts for an estimated 4 per cent by weight of total production of staple foods in PNG compared with 2 per cent for $D$. alata. The most important staple foods in 2000 were sweet potato (64 per cent), banana (10 per cent), cassava (6 per cent), all yam species (6 per cent), Colocasia taro (5 per cent), Xanthosoma taro (5 per cent), coconut ( 2 per cent) and sago (2 per cent) (Bourke and Vlassak 2004). Sago makes a greater contribution to food energy because this figure is for dry sago.
} 


\section{Environmental influences on food crop distribution and production}

\section{Temperature}

In New Guinea, temperature differences are largely determined by altitude. There is a close and linear relationship between altitude and temperature, with a decline in the maximum, mean and minimum temperature of $5.2^{\circ} \mathrm{C}$ for every $1000 \mathrm{~m}$ increase in altitude. This is known as the lapse rate. The average temperature can be predicted for any altitude in PNG. The following formulas can be used to calculate the maximum, minimum and mean temperatures for locations away from the coast:

$\mathrm{Y}_{\text {max. }}=32.67-(0.0052 \times \mathrm{a})$

$\mathrm{Y}_{\text {ann. }}=27.32-(0.0052 \times \mathrm{a})$

$\mathrm{Y}_{\text {min. }}=22.08-(0.0052 \times \mathrm{a})$

where $\mathrm{Y}_{\text {max. }}, \mathrm{Y}_{\text {ann. }}$ and $\mathrm{Y}_{\text {min. }}$ are mean maximum, mean annual and mean minimum air temperatures $\left({ }^{\circ} \mathrm{C}\right)$ respectively and $\mathrm{a}$ is the altitude in metres (Allen and Bourke 2009: 68).

This relationship is modified near the coast because of the heat stored in the ocean. Hence the minimum temperature is somewhat higher and the maximum temperature is somewhat lower at coastal locations than would be predicted from the lapse rates. A number of other factors have a smaller influence on temperature differences. Seasonal differences are generally minimal, but are somewhat greater at locations further from the equator, particularly from about $8^{\circ}$ south in Oro, Milne Bay and Central Provinces and the southern part of Western Province. Where the wettest part of the year coincides with the southern hemisphere winter, temperatures tend to be lower again in the winter. Even so, the maximum difference between mean temperatures in February and July does not exceed $5^{\circ} \mathrm{C}$ at any location.

The lapse rates tend to be somewhat less on the smaller islands, such as New Britain or New Ireland. This can be inferred from crop altitudinal limits. Diurnal temperature differences, namely the difference between day and night temperatures, vary somewhat between environments. At coastal locations on New Guinea, the typical diurnal temperature range is $7-8^{\circ} \mathrm{C}$. This is greater in inland locations and is typically about $11^{\circ} \mathrm{C}$ in the highland valleys. The diurnal range tends to be less on smaller islands. For example, on Kiriwina Island, an atoll in the Trobriand group, the diurnal range is $4-6^{\circ} \mathrm{C}$. Temperature influences the distribution and productivity of food plants in a number of ways, as discussed below.

\section{Limits to growth}

Minimum and maximum temperatures set altitudinal limits to where a crop will grow. Minimum temperatures more commonly set the limit, that is, a crop will grow up to a certain altitude where that minimum occurs. For some crops, it is the maximum temperature that sets a lower altitudinal limit. Because of the close association between altitude and temperature, it is possible to define the upper and lower altitudes at which crops grow.

As mentioned, between 1979-1984 I recorded the upper and lower limits for over 230 crop species in PNG. For each species the upper and lower usual and extreme limits were recorded at many locations. The usual limit for a location was defined as where the crop produced its economic product and was usually grown. An extreme limit was where the highest or lowest recording was made or where the crop was grown under unusual circumstances, for example, an isolated plant protected from cold by a building. 
These recordings were made before current climate change had much impact in PNG. Temperature increases accelerated in the early to late 1970s. Since these recordings were made, temperatures have increased by up to $1^{\circ} \mathrm{C}$ and crops are bearing at higher altitudes in the highlands (Allen and Bourke 2009: 75-77). For the particular case of coconut see Table 4.4, note 2. The distribution of a particular crop at any given time will be influenced by adaptation, aided by human selection, as well as climatic conditions. The relative significance of these factors is generally unknown. However, climatic conditions are likely to have a more significant influence than adaptation at the margins of a crop's distribution. This would include climatic shifts during the Holocene that are the subject of discussion in Chapter 14, sections 'Responses to drought' and 'El Niño and Phase 4' and Chapter 15, section 'The wider context of mediaeval warming'.

The mean usual and extreme altitudinal ranges for 70 species of food crops that were present in PNG before 1870 are given in Tables 4.1-4.4. An example of how to use the tables is given for aibika, the first crop in Table 4.2. The mean usual altitudinal range is from sea level $(0 \mathrm{~m})$ to $1900 \mathrm{~m}$. There were 20 observations made on the mean upper limit and the standard deviation was $110 \mathrm{~m}$. So the mean usual maximum can be read as $1900 \pm 110 \mathrm{~m}$. The highest plants observed that bore the economic product (leaves) were at $2110 \mathrm{~m}$.

Most food crops grow from sea level to a defined altitude, but some of the 'highland' species do not normally grow near sea level. Thus in broad terms there are fewer available species with increasing altitude. Many of the tree crops cease bearing their economic product at about 800-1200 m, for example, breadfruit, sago, ton, golden apple, Malay apple, coconut, Pangium edule and okari nut. A limited number of species do not bear above 500-700 m, including galip and pao nut. A number of species cease producing in a band at about 1800-2000 m altitude, including three species of yam, cucumber, ginger, hyacinth bean, winged bean and lowland pitpit (Tables 4.1-4.4). These altitudinal bands where crops cease to grow provide the basis for the definition of altitudinal zones in PNG: ${ }^{6}$

- lowlands (sea level to $600 \mathrm{~m}$ )

- intermediate $(600-1200 \mathrm{~m})$

- highlands (1200-1800 m)

- high altitude (1800-2400 m)

- very high altitude $(2400-2800 \mathrm{~m})$

- uninhabited (>2800 m)

Irregular frosts occur in the New Guinea highlands and are usually associated with El NiñoSouthern Oscillation (ENSO) events. While frosts have been recorded as low as $1450 \mathrm{~m}$ altitude, for example in 1997, they are uncommon below an altitude of $2000 \mathrm{~m}$. Repeated and severe frosts, which occur at $2200 \mathrm{~m}$ and above, kill most food plants. Only a limited number of introduced species, such as round cabbage, can survive such frosts.

\section{Productivity}

The diurnal range has an influence on plant productivity. Where soil moisture and plant nutrients are not limiting growth, plants produce more where the diurnal range is greater. This is because plants convert carbon dioxide (from the atmosphere) into carbohydrate in bright sunshine in the day, but convert some of the carbohydrate back to carbon dioxide at night. These processes are

6 The high altitude and very high altitude zone are sometimes combined. The original zonation was developed by what at the time was the CSIRO Division of Water and Land Resources (Bellamy 1986: 84) and the cut-offs were in thousands of feet, for example the lowland zone was $0-2000$ feet. Using $500 \mathrm{~m}$ instead of $600 \mathrm{~m}$ bands would have been equally valid. 
dependent on temperature. A larger difference in temperature between day and night will result in greater net generation of carbohydrate. So the ideal conditions for plant growth are abundant soil moisture, plant nutrients, sunshine and a large diurnal temperature range.

In the PNG context, this means that the highland valleys have ideal conditions for high plant productivity. While time to maturity is somewhat slower than in the lowlands because of lower temperature (see below), productivity tends to be greater in the highland valleys, at least where rainfall is adequate but not excessive and soils are fertile. The Wahgi Valley meets all of these criteria and is one of the most productive environments in PNG, as is the Asaro Valley west of Goroka. Where diurnal temperature differences are very small, particularly on small islands, plant productivity is low.

\section{Rate of growth}

Temperatures influence the rate at which plants grow. For example, Colocasia taro matures in 6-9 months at 0-200 m, but requires 8-12 months at 1600-1800 m altitude. Similarly, sweet potato matures at 3-5 months at $0-200 \mathrm{~m}$ altitude, 5-8 months at $1600-1800 \mathrm{~m}$ and $8-12$ months at $2200-2600 \mathrm{~m}$.

A slower rate of growth is not necessarily a problem in the highlands. This is because insufficient bright sunshine may limit growth in PNG given the high levels of cloud cover. So where plants have a longer period to move through their growth cycle, there is more time for them to accumulate carbohydrate. Hence yields per unit area tend to be higher in the highland valleys than in the lowlands. Because the growing period is longer, the yield per unit area per unit time may be similar. For example, experimental yields of sweet potato are typically 12-18 tonnes/ hectare (t/ha) on fertile soils in coastal locations, but $20-30 \mathrm{t} / \mathrm{ha}$ on fertile soils at $1600-1800 \mathrm{~m}$ in the highlands. In both cases, production is about $3.8 \mathrm{t} / \mathrm{ha} / \mathrm{month}$. However, because labour inputs do not change with a somewhat longer growing period, the returns to labour, measured as kilogram of food per person-day of labour input, are generally higher in the highlands.

\section{Producing period}

For a limited number of crops in PNG, temperature influences the producing period. One such crop is marita pandanus (Pandanus conoideus). This was and remains an important source of vegetable oil in most inland locations on the island of New Guinea up to the crop's altitudinal limit at $1700 \mathrm{~m}$. Marita fruits more or less continuously near sea level, but the producing period declines in a linear manner with increasing altitude. Near the upper altitudinal limit at $1600-1700 \mathrm{~m}$, fruit is available for about four months, typically from January to April.

It can be noted that the harvesting period for marita is quite predictable from year to year, unlike karuka nut pandanus (P. julianettii and P. brosimos), suggesting that flowering in marita is triggered by changes in day length (and perhaps temperature), but not soil moisture. The longer bearing period at lower altitudes is exploited by villagers who live on the highlands fringe or who have access to land in deep valleys. Because their marita fruit matures before that of people inhabiting higher altitudes $(1500-1700 \mathrm{~m})$, they are able to give marita fruit to trading partners or kin living there.

\section{Soil moisture}

Available soil moisture for plants is determined by rainfall, soil texture (with clay soils able to hold more available moisture), soil depth, runoff, evaporation and drainage. Rainfall is generally high to very high in PNG, ranging from 1000 to over $9000 \mathrm{~mm}$ per year. In some locations, more rain falls during the period November to March; in others, the wetter period is May to September; and in others, rainfall is distributed evenly throughout the year. Rainfall distribution 
is seasonal in the eastern part of the highlands, less so further west and non-seasonal further west again (Fig. 4.1). The driest part of the highlands is the Henganofi area in Eastern Highlands Province, which experiences five dry months per year and mean annual rainfall of $1800 \mathrm{~mm}$ per year. ${ }^{7}$ Rainfall elsewhere in the northern part of the eastern highlands is somewhat higher and less seasonal, with 3-4 dry months per year. Rainfall increases in a westerly direction, so that the Wahgi Valley receives about $2600 \mathrm{~mm}$ per year, with no dry month. There is a zone with no seasonal rainfall distribution that extends west from the southern part of Simbu Province through the highlands to the Indonesian border (Zone A0 in Fig. 4.1).

Adequate supply of available soil moisture is vital for plant growth. Most of the food crops in PNG require high moisture levels, but there are significant differences between the major crops. Taro thrives where soil moisture is high and can be grown successfully under flooded conditions. In the lowlands it requires flowing water, but in the highlands it appears to grow well in stagnant water, for example, on the edge of flooded limestone dolines. In contrast, yams only grow and produce well in drier soils and are tolerant of mild water stress. Banana is a flexible crop regarding water needs and tolerates a range of soil moisture conditions. Banana is an important staple food in lowland locations where rainfall is continuously heavy, for example in inland Gulf and Western Provinces, as well as in locations that experience several months of water stress each year, for example in the Markham Valley of Morobe Province and coastal Central Province. They are also an important food in locations where there is only mild water stress, such as on the Gazelle Peninsula of New Britain.

In the PNG lowlands villagers used different combinations of their staple foods to maintain a continuous food supply throughout the year, given that only yam and sago can be stored postharvest. This strategy continues in the lowlands, although provision of a continuous food supply has been made much easier since the widespread adoption of sweet potato, cassava, Xanthosoma taro and consumption of purchased rice and wheat-based foods. Where rainfall was high and there were no dry months on average each year, taro was the main staple food. At locations where the rainfall was somewhat lower and rainfall distribution seasonal, people planted more yam (Dioscorea esculenta and D. alata) and banana. The proportion of yam and banana increased as seasonality increased. Such a cline could be observed in many lowland locations, for example from Madang to Bogia or on the Gazelle Peninsula of New Britain or in southeast New Guinea. In some locations, sago was used to fill the gap.

It is no longer possible to observe these combinations of taro, banana and yam in the highlands because of the dominance of sweet potato. Nevertheless, the strategy of using a combination of food crops is still practised in seasonally dry parts of the highlands. In the northern parts of Eastern Highlands Province, where rainfall seasonality is greater and there is a longer dry season (D2 and $\mathrm{C} 1 / \mathrm{C} 2$ on Fig. 4.1), yam (mainly D. alata) is grown to supplement sweet potato. In recent decades, cassava and maize have been widely adopted in this environment as both provide food when sweet potato is less available.

7 A dry month is defined as one in which the mean monthly rainfall is less than $100 \mathrm{~mm}$. 


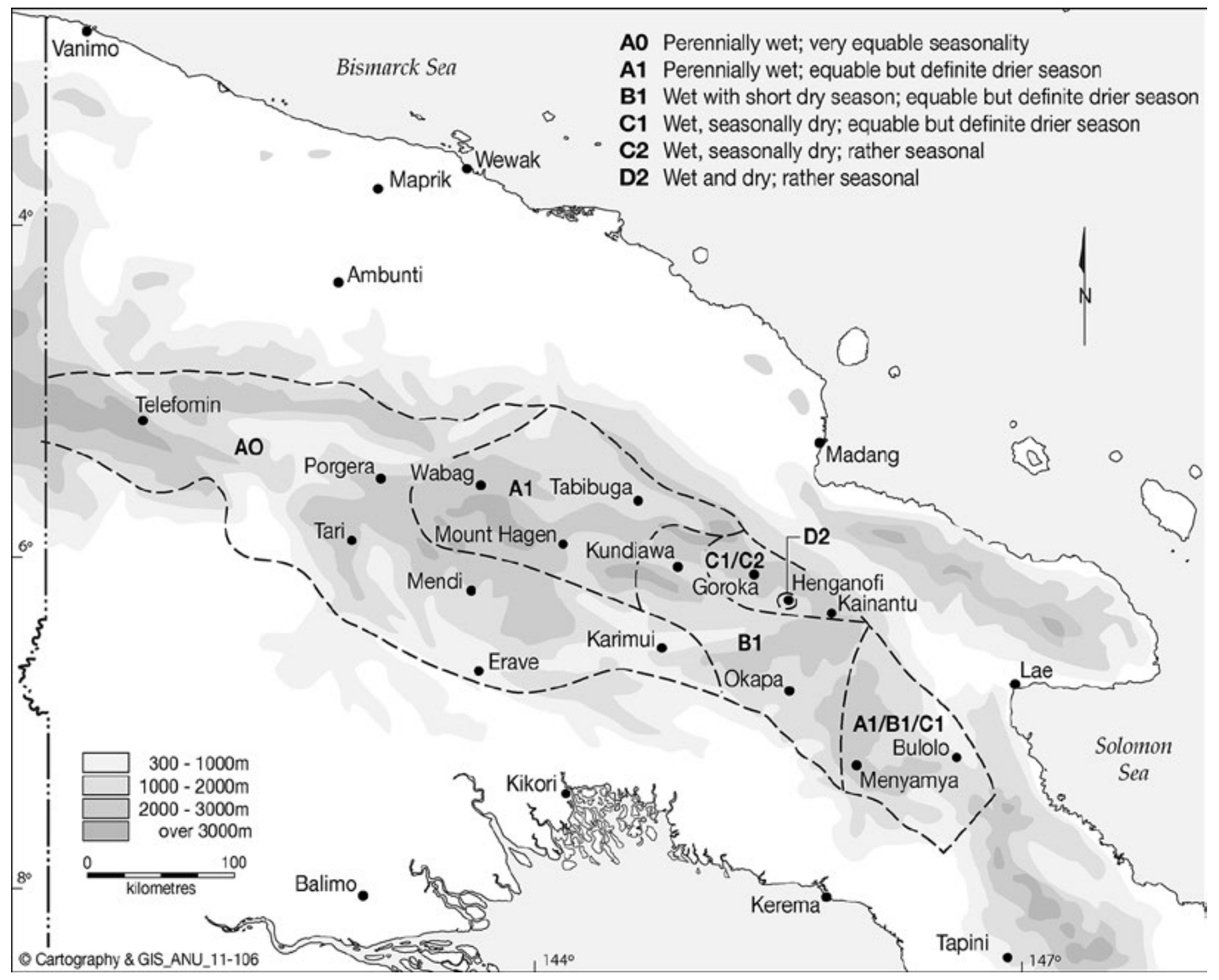

Figure 4.1 Climatic types in the PNG highlands based on rainfall seasonality.

Source: Keith Mitchell, Cartography, College of Asia and the Pacific, ANU.

In this drier area of the Eastern Highlands Province, the staple food before sweet potato would have been taro supplemented by yam and banana. In those locations with 3-5 dry months each year, irrigation of taro would have resulted in a more even supply of food throughout the year. Taro irrigation has been recorded in a number of locations in the Eastern Highlands Province over the past 50 years, including the Lamari Valley and adjacent valleys near Okapa. It is now a minor practice, but it is likely to have been more significant in the past before sweet potato became an important food in recent decades. In the Arona Valley east of Kainantu it seems that people once targeted natural terraces that retained water from surface runoff and subsoil seepage for growing taro. This is inferred from the presence of modest ditching systems predating the sweet potato that enhance water collection and distribution in an area where taro is not an important crop today (Golson and Gardner 1990: 410). Further west, including in the Wahgi Valley, there would have been less need to grow significant amounts of yam and banana as the supply of taro would have been more constant throughout the year.

Regular or irregular periods of lower rainfall lead to water stress in plants. Such stress stimulates flowering in many plant species. Given the high rainfall in most of PNG, even mild water stress can lead to flowering. This is the case for karuka nut pandanus (P. julianettii). In the eastern highlands, flowering and fruiting is somewhat irregular, but approximates to an annual pattern, with fruit maturing from about February. In the western part of the highlands where annual water stress is slight or absent, fruiting is more irregular and does not follow an annual pattern (Bourke et al. 2004: 40). Large harvests of karuka nut generally occur after droughts, such as 
those in 1972,1979 and $1982 .{ }^{8}$ Both the size and timing of the nut harvest vary considerably from year to year and between locations in the western part of the highlands. Thus the fruiting period for planted karuka nut (Pandanus julianettii) and the wild species (P. brosimos) cannot be predicted from year to year.

\section{Cloud cover}

Cloud cover is determined by total annual rainfall, local patterns of cloud build-up during the course of a day, and terrain. High levels of cloud cover reduce the amount of bright sunshine, which is needed for optimum plant growth. Cloud cover is generally high in the highlands and the highlands fringe in New Guinea, but there is less cloud cover and hence greater plant productivity in some of the main valleys, including the Wahgi Valley.

\section{Slope}

Much of PNG is mountainous and hence much of the landscape has a steep slope. Slope influences a number of other environmental factors that affect plant growth. These include soil depth, and hence soil fertility, with deeper soils generally being more fertile, as well as moisture retention and runoff, with greater runoff on steep slopes and more infiltration on gentle slopes. Steeper land is commonly used in preference to flat land for sweet potato production as sweet potato is intolerant of excessive soil moisture and steep land is better drained. In contrast, taro tolerates higher levels of soil moisture, so there is no advantage in using very steep land for its cultivation.

\section{Day length}

Seasonal differences in day length are slight near the equator, such as on Manus Island, and somewhat greater at $8-12^{\circ}$ south, that is in Milne Bay, Oro and Central Provinces and the southern part of Western Province. The difference between the length of the longest and the shortest day at Lorengau $\left(2^{\circ} 1^{\prime} \mathrm{S}\right)$ is only 14 minutes, whereas at Port Moresby $\left(9^{\circ} 27^{\prime} \mathrm{S}\right)$ it is 66 minutes (McAlpine et al. 1983: 119).

Differences in day length influence flowering of some species, including marita pandanus, Pangium edule, lowland pitpit (Saccharum edule) and probably breadfruit. Breadfruit bears in a regular seasonal manner at $8^{\circ} \mathrm{S}$ and further south, but not at locations nearer the equator in PNG. Seasonal differences in day length do not influence crop distribution or productivity of taro, banana, yam or sago. The producing period of marita pandanus fruit and Pangium edule nuts at a particular location is predictable, thus both species can be relied upon as seasonal food sources.

\section{Soil fertility}

Soil fertility has a major influence on productivity of plants. It is determined by the inherent fertility of the land, slope, fallow period, cropping period and human inputs. Soil fertility is usually maintained by natural fallows. People enhance it using a number of techniques, including placing green manure on the soil surface, which may be covered with soil (as is done in the composted mound systems in the highlands) or without being covered by soil (as is done in taro plots on atolls). Other techniques used include planting nitrogen-fixing trees, particularly Casuarina oligodon in the highlands, so that fallow periods are reduced, and rotating root and leguminous crops in a sequence.

8 There was not a large crop of karuka pandanus nuts after the major drought of 1997. It seems that this drought was so severe as to inhibit flowering. 
Soil fertility has minimal influence on the distribution of food crops in PNG. Where soil fertility is very low, taro and yam may not yield. This is now the situation on a number of very small islands where population pressure is very high and soil fertility has been reduced by extended periods of cropping without adequate fallows. However, this is a recent phenomenon and is unlikely to have been a limiting factor until recent times.

In contrast, differences in soil fertility have a major influence on plant productivity. The most productive soils in PNG are those derived from volcanic ash and alluvium. The deep soils in the Wahgi Valley, formed on these materials, are among the most productive in PNG.

\section{Discussion}

Temperature, which is largely determined by altitude, is the most important factor determining where crops can be grown in PNG. This is because it sets the absolute limits to growth. The other major environmental factors of soil moisture, cloud cover, day length and soil fertility have a greater influence on plant productivity, but they are in general less critical in determining where crops can be grown. However, inundation does limit agriculture and where land is inundated for extended periods, only a limited number of food crops grow, sago being the most important.

The current altitudinal distribution of food crops can be used to make inferences about crop distribution under different temperature regimes in the past. Taro, supplemented by banana and yam (Dioscorea alata with some D. bulbifera and D. nummularia), is likely to have been the most important food in the highlands before the adoption of sweet potato about 300 years ago. In the early 1980s, monocultures of taro were uncommon above $2200 \mathrm{~m}$ altitude, although individual plants were grown up to $2400 \mathrm{~m}$ and occasionally as high as $2760 \mathrm{~m}$ (Table 4.1). Some types of banana yielded at up to $2150 \mathrm{~m}$ and occasionally as high as $2580 \mathrm{~m}$. D. alata yam and the other two species grown in the highlands yield at up to $1900 \mathrm{~m}$, and occasionally as high as $2100 \mathrm{~m}$ (Table 4.1).

Based on these observations, it is concluded that, when temperature conditions were similar to those prevailing in about 1980, the upper limit for agriculture in PNG occurred at about $2200 \mathrm{~m}$, and occasionally as high as $2400 \mathrm{~m}$, before the adoption of sweet potato. A limited number of other crops, including sugarcane and some vegetables, such as Rorippa schlechter, oenanthe, rungia and highland pitpit could have been grown at higher altitudes, but they would not have been sufficient to meet the energy needs of people (Table 4.2). The cultivated and wild form of karuka nut pandanus (P. julianettii and $P$. brosimos) grow up to $2600 \mathrm{~m}$ and $3100 \mathrm{~m}$ respectively (Table 4.4). These would have provided valuable vegetable oil and protein in people's diets for part of the year, but the producing period was not reliable from year to year, particularly in the western part of the highlands where rainfall seasonality is weak or absent.

The upper Wahgi Valley, including the Kuk archaeological site, lies at about $1600 \mathrm{~m}$ altitude, that is, it is about $600 \mathrm{~m}$ lower than the suggested upper limit for agriculture based on taro, banana and yam. If the mean minimum and maximum temperatures were $3^{\circ} \mathrm{C}$ lower than they were in 1980, then the upper Wahgi Valley would have been at the upper limit for agricultural production. If temperatures were $5^{\circ} \mathrm{C}$ lower than the 1980 means, Kuk would have been too cold for taro, banana or yam production. During the last glacial maximum at around 21,000 years ago, the highland valleys between $1500-1700 \mathrm{~m}$ altitude were as much as $7^{\circ} \mathrm{C}$ cooler than their mean temperatures in about 1980, with frequent frosts and drought (Hope and Haberle 2005). Thus the highland valleys could not have supported taro and banana at that time. Warming in 
the Late Pleistocene period after about 15,000 years ago would have meant that taro and banana could grow as high as $1600 \mathrm{~m}$ once temperature increased to a point where it was no more than $3^{\circ} \mathrm{C}$ lower than that at around $\mathrm{AD} 1980$.

The upper Wahgi Valley has an ideal environment for agricultural production, with an adequate but not excessive rainfall; mild temperatures in which crops mature more slowly and have time to accumulate more carbohydrate; less cloud cover to limit plant growth; and very fertile soils, particularly when swamps are drained of excessive water. Plant productivity is high in the valley, with good yields per unit area recorded for sweet potato, taro and cassava (Bourke et al. 2009: 149, 153). Perhaps it is not surprising that the upper Wahgi Valley is the site of some of the earliest documented agriculture in the world.

\section{Acknowledgements}

I am grateful to Jack Golson for guidance on the focus of this chapter; and to Chris Ballard, Jack Golson and two anonymous referees for comments on earlier drafts. 
This text is taken from Ten Thousand Years of Cultivation at Kuk Swamp in the Highlands of Papua New Guinea, edited by Jack Golson, Tim Denham, Philip Hughes, Pamela Swadling and John Muke, published 2017 by ANU Press, The Australian National University, Canberra, Australia. 